Article

\title{
Investigation of Chemical Constituents of Eranthis longistipitata (Ranunculaceae): Coumarins and Furochromones
}

\author{
Andrey S. Erst ${ }^{1,2, *}$, Alexander A. Chernonosov ${ }^{3}{ }^{\circledR}$, Natalia V. Petrova ${ }^{4}\left(\mathbb{D}\right.$, Maxim S. Kulikovskiy $^{5}$, \\ Svetlana Yu. Maltseva ${ }^{5}\left(\mathbb{D}\right.$, Wei Wang ${ }^{6}(\mathbb{B})$ and Vera A. Kostikova ${ }^{1, *}{ }^{(1)}$
}

1 Central Siberian Botanical Garden, Siberian Branch of Russian Academy of Sciences, CSBG SB RUS, 630090 Novosibirsk, Russia

2 Laboratory Herbarium (TK), Tomsk State University, 634050 Tomsk, Russia

3 Institute of Chemical Biology and Fundamental Medicine, Siberian Branch of Russian Academy of Sciences, ICBFM SB RAS, 630090 Novosibirsk, Russia; alexander.chernonosov@niboch.nsc.ru

4 Komarov Botanical Institute, Russian Academy of Sciences, BIN RAS, 197376 St. Petersburg, Russia; npetrova@binran.ru

5 K.A. Timiryazev Institute of Plant Physiology RAS, IPP RAS, 127276 Moscow, Russia; max-kulikovsky@yandex.ru (M.S.K.); svetadm32@gmail.com (S.Y.M.)

6 Institute of Botany, Chinese Academy of Sciences, IB CAS, Beijing 100093, China; wangwei1127@ibcas.ac.cn

* Correspondence: erst_andrew@yahoo.com (A.S.E.); serebryakova-va@yandex.ru (V.A.K.); Tel.: +7-(923)-641-2466 (A.S.E.); +7-(383)-339-9810 (V.A.K.)

check for updates

Citation: Erst, A.S.; Chernonosov, A.A.; Petrova, N.V.; Kulikovskiy, M.S.; Maltseva, S.Y.; Wang, W.; Kostikova, V.A. Investigation of Chemical Constituents of Eranthis longistipitata (Ranunculaceae): Coumarins and Furochromones. Int. J. Mol. Sci. 2022, 23, 406. https:// doi.org/10.3390/ijms23010406

Academic Editor: Jin Boo Jeong

Received: 17 December 2021

Accepted: 29 December 2021

Published: 30 December 2021

Publisher's Note: MDPI stays neutral with regard to jurisdictional claims in published maps and institutional affiliations.

Copyright: (C) 2021 by the authors. Licensee MDPI, Basel, Switzerland. This article is an open access article distributed under the terms and conditions of the Creative Commons Attribution (CC BY) license (https:// creativecommons.org/licenses/by/ $4.0 /)$.

\begin{abstract}
Aqueous-ethanol extracts (70\%) from the leaves of Eranthis longistipitata Regel. (Ranunculaceae Juss.) — collected from natural populations of Kyrgyzstan-were studied by liquid chromatography with high-resolution mass spectrometry (LC-HRMS). There was no variation of the metabolic profiles among plants that were collected from different populations. More than 160 compounds were found in the leaves, of which 72 were identified to the class level and 58 to the individual-compound level. The class of flavonoids proved to be the most widely represented (19 compounds), including six aglycones [quercetin, kaempferol, aromadendrin, 6-methoxytaxifolin, phloretin, and (+)-catechin] and mono- and diglycosides (the other 13 compounds). In the analyzed samples of E. longistipitata, 14 fatty acid-related compounds were identified, but coumarins and furochromones that were found in E. longistipitata were the most interesting result; furochromones khelloside, khellin, visnagin, and cimifugin were found in E. longistipitata for the first time. Coumarins 5,7-dihydroxy-4-methylcoumarin, scoparone, fraxetin, and luvangetin and furochromones methoxsalen, 5-O-methylvisammioside, and visamminol-3'-O-glucoside were detected for the first time in the genus Eranthis Salisb. For all the above compounds, the structural formulas are given. Furthermore, detailed information (with structural formulas) is provided on the diversity of chromones and furochromones in other representatives of Eranthis. The presence of chromones in plants of the genus Eranthis confirms its closeness to the genus Actaea L. because chromones are synthesized by normal physiological processes only in these members of the Ranunculaceae family.
\end{abstract}

Keywords: Ranunculaceae; Eranthis longistipitata; LC-HRMS; chemical composition; coumarin; furochromone; fatty acid; extract

\section{Introduction}

Plant extracts are most often multicomponent mixtures and, therefore, it is difficult to analyze individual substances there. Liquid chromatography coupled with mass spectrometry (LC-MS) is widely used as a powerful tool for the analysis of substances in plant extracts. Recently, with the development of various analytical methods, such as high-resolution mass spectrometry (HRMS), it became possible to quickly and selectively identify components in extracts. Due to its high accuracy and analytical sensitivity, LC-HRMS greatly facilitates the identification of known and unknown compounds in extracts [1,2]. Furthermore, 
this method does not require a large amount of plant material for the assay; this feature is undoubtedly suitable for studying plants with a small geographic range and limited occurrence in nature. Such plants include almost all members of the genus Eranthis Salisb.

The genus Eranthis belongs to Ranunculaceae Juss. Tribe Cimicifugeae Torr. \& A. Grey [3]. This genus consists of 10 to 13 early flowering herbaceous perennial species that are distributed across Southern Europe and Western, Central, and temperate Asia [4-7]. Species of this genus have rarely been the subject of phytochemical research. Examination of the literature indicates that triterpene glycosides and saponins have been studied (along with their biological activity) in E. cilicica Schott \& Kotschy [8,9]. The set of flavonoids has been investigated in E. sibirica DC., E. stellata Maxim., E. longistipitata Regel., and E. tanhoensis Erst $[10,11]$. Nonetheless, the chromones that were found in E. cilicica, E. pinnatifida Maxim., and E. hyemalis (L.) Salisb. Are the most intriguing finding [12-16], and the same is true for another family of benzo- $\alpha$-pyrone derivatives: coumarins. In contrast to other classes of Eranthis chemical constituents, which are widespread in the plant kingdom and have been studied sufficiently, the limited occurrence of chromones and coumarins and their pharmacological activity are of much interest.

The aim of this work was to identify numerous chemical compounds in extracts from E. longistipitata leaves by LC-HRMS for subsequent chemotaxonomic, phytochemical, and pharmacological studies.

\section{Results}

Compounds belonging to such classes as amino acids, flavonoids, and fatty and organic acids - as well as their derivatives, alcohols, sugars, coumarins, furochromones, and others-were analyzed by mass spectrometry (LC-HRMS) in E. longistipitata leaves (in $70 \%$ aqueous-ethanol extracts) from natural populations growing in Kyrgyzstan (Table 1 and Figure 1). For identification of compounds, the mass spectrometry (MS) data acquired in negative and positive electrospray ionization $\left(\mathrm{ESI}^{-} / \mathrm{ESI}^{+}\right)$modes were compared with information in the $\mathrm{mzCloud}$ database. There was a $\leq 99.9 \%$ match of the mass spectra between the compounds obtained by us and compounds from the mzCloud database (Table 1). A more detailed procedure for identifying substances is described in Ref. [11].

Table 1. Chemical constituents identified in E. longistipitata leaves (aqueous-ethanol extracts) using LC-HRMS, mzCloud, and ChemSpider.

\begin{tabular}{|c|c|c|c|c|c|c|c|}
\hline Identified Compounds & $\begin{array}{c}t_{R} \\
(\min )\end{array}$ & $\begin{array}{l}\text { Calculated } \\
\text { Mass }\end{array}$ & $\begin{array}{l}\text { Measured } \\
\text { Mass }\end{array}$ & $\begin{array}{l}\text { Delta Mass } \\
\text { [Da] }\end{array}$ & $\begin{array}{l}\text { Delta Mass } \\
\text { [ppm] }\end{array}$ & $\begin{array}{l}\text { MzCloud } \\
\text { Score }\end{array}$ & Mode \\
\hline \multicolumn{8}{|c|}{ Flavonoids } \\
\hline Quercetin * & 11.29 & 302.0426 & 302.0423 & -0.00035 & -1.15 & 99.9 & Positive \\
\hline $\begin{array}{c}\text { Isoquercitrin } \\
\text { (quercetin-3-O- } \beta \text {-D-glucoside) }\end{array}$ & 13.01 & 464.0954 & 464.0958 & 0.00035 & 0.75 & 99.2 & Negative \\
\hline $\begin{array}{c}\text { Hyperoside * } \\
\text { (quercetin 3-O- } \beta \text {-D-galactoside) }\end{array}$ & 10.95 & 464.0954 & 464.0952 & -0.00024 & -0.51 & 98.2 & Positive \\
\hline $\begin{array}{l}\text { Reynoutrin } \\
\text { (quercetin-3-O- } \beta \text {-D- } \\
\text { xylopyranoside) }\end{array}$ & 10.95 & 434.0849 & 434.0846 & -0.00031 & -0.72 & 98.7 & Positive \\
\hline $\begin{array}{l}\text { Quercetin-6-O- } \beta \text {-D- } \\
\text { xylopyranosyl- } \beta \text {-D- } \\
\text { glucopyranoside }\end{array}$ & 11.65 & 596.13773 & 596.13714 & -0.0006 & -1 & 98.1 & Negative \\
\hline $\begin{array}{l}\text { Quercetin 3-sambubioside } \\
\text { (quercetin-3-O-[ } \beta \text {-D-xylosyl- } \\
\quad(1 \rightarrow 2)-\beta \text {-D-glucoside] })\end{array}$ & 11.66 & 596.1377 & 596.1371 & -0.00060 & -1.00 & 98.1 & Negative \\
\hline
\end{tabular}


Table 1. Cont.

\begin{tabular}{|c|c|c|c|c|c|c|c|}
\hline Identified Compounds & $\underset{(\min )}{t_{R}}$ & $\begin{array}{l}\text { Calculated } \\
\text { Mass }\end{array}$ & $\begin{array}{l}\text { Measured } \\
\text { Mass }\end{array}$ & $\begin{array}{c}\text { Delta Mass } \\
\text { [Da] }\end{array}$ & $\begin{array}{l}\text { Delta Mass } \\
\text { [ppm] }\end{array}$ & $\begin{array}{l}\text { MzCloud } \\
\text { Score }\end{array}$ & Mode \\
\hline $\begin{array}{c}\text { Peltatoside } \\
\text { (quercetin-3-(6-O- } \alpha \text {-L- } \\
\text { arabinopyranosyl)- } \beta-\mathrm{D}- \\
\text { glucopyranoside) })\end{array}$ & 10.13 & 596.1377 & 596.1368 & -0.00084 & -1.42 & - & Positive \\
\hline $\begin{array}{l}\text { Rutin * } \\
\text { (quercetin 3-O- } \beta \text {-D- } \\
\text { rutinoside) }\end{array}$ & 12.48 & 610.1533 & 610.1524 & -0.00089 & -1.46 & 98.9 & Positive \\
\hline Kaempferol * & 11.90 & 286.0477 & 286.0475 & -0.00023 & -0.80 & 99.0 & Positive \\
\hline $\begin{array}{c}\text { Juglalin } \\
\text { (kaempferol 3-O- } \alpha-\mathrm{L}- \\
\text { arabinopyranoside) }\end{array}$ & 11.90 & 418.0900 & 418.0896 & -0.00033 & -0.79 & 79.8 & Positive \\
\hline $\begin{array}{c}\text { Trifolin } \\
\text { (kaempferol-3-O- } \beta-\mathrm{D}- \\
\text { galactoside) }\end{array}$ & 11.90 & 448.1005 & 448.1003 & -0.00024 & -0.54 & 98.5 & Positive \\
\hline $\begin{array}{c}\text { Carlinoside } \\
\text { (luteolin } 6-C-\beta-\mathrm{D}- \\
\text { glucopyranoside- } 8-C-\alpha-\mathrm{L}- \\
\text { arabinopyranoside) }\end{array}$ & 12.56 & 580.1428 & 580.1425 & -0.00023 & -0.40 & - & Negative \\
\hline $\begin{array}{c}\text { Cianidanol } \\
{[(+) \text {-catechin }]}\end{array}$ & 16.53 & 290.0790 & 290.0789 & -0.00003 & -0.11 & - & Positive \\
\hline $\begin{array}{c}\text { Auriculoside } \\
\left(7,3^{\prime}, 5^{\prime} \text {-trihydroxy- } 4^{\prime}-\right. \\
\text { methoxyflavan-3' -glucoside })\end{array}$ & 19.78 & 450.1526 & 450.1521 & -0.00045 & -0.99 & - & Positive \\
\hline 6-Methoxytaxifolin & 14.55 & 334.0688 & 334.0690 & 0.00016 & 0.48 & - & Negative \\
\hline $\begin{array}{c}\text { Aromadendrin } \\
((+) \text {-dihydrokaempferol) }\end{array}$ & 21.50 & 288.0633 & 288.0633 & -0.00003 & -0.11 & - & Positive \\
\hline Aspalathin & 15.45 & 452.1318 & 452.1317 & -0.00014 & -0.32 & - & Positive \\
\hline $\begin{array}{c}\text { Phloridzin } \\
\text { (phloretin- } 2^{\prime}-O-\beta \text {-glucoside) }\end{array}$ & 16.23 & 436.1369 & 436.1368 & -0.00013 & -0.30 & - & Positive \\
\hline $\begin{array}{c}\text { Phloretin } \\
\text { (dihydroxy naringenin) }\end{array}$ & 20.80 & 274.0841 & 274.0839 & -0.00019 & -0.69 & - & Positive \\
\hline \multicolumn{8}{|c|}{ Fatty acids-related compounds } \\
\hline 12-Oxo-phytodienoic acid & 36.84 & 292.2038 & 292.2037 & -0.00013 & -0.43 & 87.3 & Positive \\
\hline $\begin{array}{c}\text { 15-OxoEDE } \\
\text { (15-Oxo-11Z,13E-eicosadienoic } \\
\text { acid) }\end{array}$ & 47.47 & 322.2507 & 322.2508 & 0.00006 & 0.2 & 91.7 & Positive \\
\hline $\begin{array}{l}\text { 9-oxo-ODA } \\
\text { (9-Oxo-10(E),12(E)- } \\
\text { octadecadienoic } \\
\text { acid) }\end{array}$ & 39.22 & 294.2194 & 294.2194 & -0.00006 & -0.21 & 95.3 & Positive \\
\hline 9S,13R-12-Oxo-phytodienoic acid & 36.47 & 292.2038 & 292.2037 & -0.00009 & -0.3 & 87.2 & Positive \\
\hline Linolenic acid ethyl ester & 46.47 & 306.2558 & 306.2558 & -0.00008 & -0.28 & 98.3 & Positive \\
\hline Palmitoleic Acid & 45.38 & 254.2245 & 254.2245 & -0.00006 & -0.24 & 86.7 & Positive \\
\hline$\alpha$-Eleostearic acid & 49.77 & 278.2245 & 278.2244 & -0.00017 & -0.62 & 99.1 & Positive \\
\hline$\alpha$-Linolenic acid & 45.50 & 278.2245 & 278.2244 & -0.00012 & -0.45 & 99.2 & Positive \\
\hline
\end{tabular}


Table 1. Cont.

\begin{tabular}{|c|c|c|c|c|c|c|c|}
\hline Identified Compounds & $\begin{array}{c}t_{R} \\
(\min )\end{array}$ & $\begin{array}{l}\text { Calculated } \\
\text { Mass }\end{array}$ & $\begin{array}{l}\text { Measured } \\
\text { Mass }\end{array}$ & $\begin{array}{l}\text { Delta Mass } \\
\text { [Da] }\end{array}$ & $\begin{array}{l}\text { Delta Mass } \\
\text { [ppm] }\end{array}$ & $\begin{array}{l}\text { MzCloud } \\
\text { Score }\end{array}$ & Mode \\
\hline $\begin{array}{c}(+/-) \text { 13-HODE } \\
\text { (13-hydroxyoctadecadienoic acid) }\end{array}$ & 38.17 & 296.2351 & 296.2352 & 0.0001 & 0.35 & 92.8 & Negative \\
\hline $\begin{array}{c}\text { (15Z)-9,12,13-Trihydroxy-15- } \\
\text { octadecenoic acid }\end{array}$ & 24.63 & 330.2406 & 330.2408 & 0.00019 & 0.57 & 68.5 & Negative \\
\hline $\begin{array}{c}\text { 13(S)-HOTrE } \\
\text { (13-OH-9Z,11E,15Z- } \\
\text { octadecatrienoic } \\
\text { acid) }\end{array}$ & 36.23 & 294.2194 & 294.2195 & 0.00009 & 0.29 & 92.1 & Negative \\
\hline 16-Hydroxyhexadecanoic acid & 44.84 & 272.2351 & 272.2353 & 0.0002 & 0.73 & 89.5 & Negative \\
\hline Corchorifatty acid F & 23.35 & 328.2249 & 328.2249 & 0.00002 & 0.06 & 93 & Negative \\
\hline Pinolenic acid & 45.76 & 278.2245 & 278.2245 & -0.0006 & -0.21 & 94.5 & Negative \\
\hline \multicolumn{8}{|c|}{ Amino acid-related compounds } \\
\hline D-(+)-Pyroglutamic Acid & 1.56 & 129.0425 & 129.0428 & 0.00021 & 1.63 & 98.2 & Positive \\
\hline D-(+)-Tryptophan & 6.96 & 204.0898 & 204.0898 & -0.0003 & -0.13 & 99.2 & Positive \\
\hline Isoleucine & 1.93 & 131.0946 & 131.0947 & 0.00014 & 1.10 & 99.2 & Positive \\
\hline L-Phenylalanine & 4.45 & 165.0789 & 165.0790 & 0.00003 & 0.19 & 98.6 & Positive \\
\hline L-Tyrosine & 1.93 & 181.0738 & 181.0740 & 0.00015 & 0.81 & 98.4 & Positive \\
\hline D-(-)-Glutamine & 1.56 & 146.0691 & 146.0684 & -0.00073 & -4.99 & 66.9 & Negative \\
\hline \multicolumn{8}{|c|}{ Organic acids } \\
\hline Citric acid & 2.00 & 192.027 & 192.0264 & -0.00056 & -2.93 & 99.6 & Negative \\
\hline D- $\alpha$-Hydroxyglutaric acid & 1.99 & 148.0371 & 148.0364 & -0.00071 & -4.81 & 68.8 & Negative \\
\hline Gluconic acid & 1.61 & 196.0583 & 196.0577 & -0.00057 & -2.89 & 99 & Negative \\
\hline \multicolumn{8}{|c|}{ Sugars } \\
\hline$\alpha$-Lactose & 1.61 & 342.1162 & 342.1160 & -0.00014 & -0.41 & 81.8 & Positive \\
\hline D-(+)-Galactose & 1.61 & 180.0633 & 180.0629 & -0.00047 & -2.61 & 60.5 & Negative \\
\hline$\alpha . \alpha$-Trehalose & 1.64 & 342.1162 & 342.1160 & -0.00019 & -0.55 & 98.9 & Negative \\
\hline \multicolumn{8}{|c|}{ Phenylpropanoid } \\
\hline 6-Gingerol & 28.34 & 294.1831 & 294.1830 & -0.00004 & -0.14 & 81.8 & Positive \\
\hline \multicolumn{8}{|c|}{ Coumarins } \\
\hline $\begin{array}{l}\text { 5,7-Dihydroxy-4- } \\
\text { methylcoumarin }\end{array}$ & 17.32 & 192.0422 & 192.0423 & 0.00007 & 0.35 & 99.9 & Positive \\
\hline $\begin{array}{c}\text { Scoparone } \\
\text { (6,7-dimethoxycoumarin) }\end{array}$ & 24.79 & 206.0579 & 206.0579 & 0.00002 & 0.12 & 98.8 & Positive \\
\hline $\begin{array}{c}\text { Fraxetin } \\
\text { (7,8-dihydroxy-6- } \\
\text { methoxycoumarin) }\end{array}$ & 11.39 & 208.0371 & 208.0371 & -0.00005 & -0.24 & 96.1 & Positive \\
\hline $\begin{array}{c}\text { Luvangetin } \\
\text { (10-methoxy-2,2- } \\
\text { dimethylpyrano[3,2-g]chromen- } \\
\text { 8-one) }\end{array}$ & 32.62 & 258.0892 & 258.0891 & -0.00005 & -0.19 & 93.6 & Positive \\
\hline
\end{tabular}


Table 1. Cont.

\begin{tabular}{|c|c|c|c|c|c|c|c|}
\hline Identified Compounds & $\begin{array}{c}\mathbf{t}_{R} \\
(\mathrm{~min})\end{array}$ & $\begin{array}{c}\text { Calculated } \\
\text { Mass }\end{array}$ & $\begin{array}{l}\text { Measured } \\
\text { Mass }\end{array}$ & $\begin{array}{c}\text { Delta Mass } \\
\text { [Da] }\end{array}$ & $\begin{array}{c}\text { Delta Mass } \\
\text { [ppm] }\end{array}$ & $\begin{array}{l}\text { MzCloud } \\
\text { Score }\end{array}$ & Mode \\
\hline \multicolumn{8}{|c|}{ Furochromones } \\
\hline $\begin{array}{c}\text { Khelloside } \\
\text { (7-hydroxymethyl-4-methoxy- } \\
\text { 5H-furo[3,2-g](1)benzopyran-5- } \\
\text { one glucoside) }\end{array}$ & 12.02 & 408.1056 & 408.1048 & -0.00077 & -1.9 & 99.5 & Positive \\
\hline $\begin{array}{c}\text { Khellin } \\
\text { (4,9-dimethoxy-7-methyl-5H- } \\
\text { furo[3,2-g]chromen-5-one) }\end{array}$ & 21.003 & 260.0684 & 260.0680 & -0.00039 & -1.5 & 99.8 & Positive \\
\hline $\begin{array}{l}\text { Visnagin } \\
\text { (4-methoxy-7-methyl-5H- } \\
\text { furo[3,2-g]chromen-5-one) }\end{array}$ & 21.138 & 230.0579 & 230.0576 & -0.00023 & -0.98 & 99.3 & Positive \\
\hline $\begin{array}{c}\text { Cimifugin } \\
\text { ((2S)-7-(hydroxymethyl)-2-(1- } \\
\text { hydroxy-1-methyl-ethyl)-4- } \\
\text { methoxy-2,3-dihydrofuro[3,2- } \\
\text { g]chromen-5-one) }\end{array}$ & 13.544 & 306.1103 & 306.1097 & -0.00061 & -1.98 & 95.1 & Positive \\
\hline $\begin{array}{c}\text { Methoxsalen } \\
\text { (9-methoxyfuro[3,2-g]chromen- } \\
\text { 7-one) }\end{array}$ & 27.757 & 216.0422 & 216.0422 & 0 & 0.02 & 99.3 & Positive \\
\hline $\begin{array}{l}\text { 5-O-Methylvisammioside } \\
\text { (4-O- } \beta \text {-D-glucosyl-5-O- } \\
\text { methylvisamminol) }\end{array}$ & 14.538 & 452.1682 & 452.1677 & -0.00048 & -1.05 & 99.1 & Positive \\
\hline $\begin{array}{c}\text { Visamminol-3'-O-glucoside } \\
\text { (4-hydroxy-2-(2-hydroxypropan-2- } \\
\text { yl)-methyl-2,3-dihydrofuro[3,2-g] } \\
\text { chromen-5-one) }\end{array}$ & 16.894 & 438.1526 & 438.1523 & -0.00022 & -0.5 & 98.2 & Positive \\
\hline
\end{tabular}

* Identification confirmed with the help of standards; the en dash means that ChemSpider was used without mzCloud.
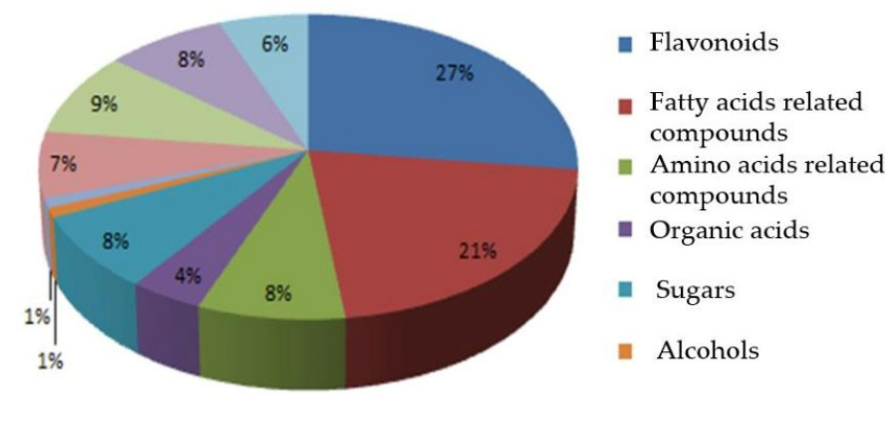

- Phenylpropanoids

Coumarins

In Furochromones

- Terpenoids

Quinones

Figure 1. Numbers (as \% of total) of bioactive compounds (by class) that were detected in E. longistipitata leaves.

\section{Discussion}

In the raw data on metabolites from E. longistipitata leaves, more than 160 compounds were found, of which, 72 were identified to the class level (Figure 1) and 58 to the individualcompound level (Table 1). After a comparison of E. longistipitata metabolomes among different populations, it turned out that these profiles of metabolites do not differ and are characterized by the presence of such classes of compounds as flavonoids, fatty acidrelated compounds, amino acid-related compounds, organic acids, sugars, alcohols, phenyl- 
propanoids, coumarins, furochromones, terpenoids, and quinones. Among the classes of substances that were identified in the leaves of E. longistipitata, the highest diversity was documented for flavonoids ( $27 \%$ of all compounds) and fatty acid-related compounds (21\%). Furochromones showed lower diversity $(9 \%)$, as did terpenoids, amino acid-related compounds, and sugars ( $8 \%$ each), coumarins $(7 \%)$, and quinones $(6 \%)$. Other classes of compounds were not so diverse in the extracts of this plant: organic acids ( $4 \%$ of all compounds), alcohols (1\%), and phenylpropanoids (1\%). We failed to find metabolomic data on Eranthis representatives, including E. longistipitata, in the literature.

\subsection{Flavonoids}

The class of flavonoids proved to be most widely represented (19 compounds), among which there were only six aglycones [quercetin, kaempferol, aromadendrin, 6-methoxytaxifolin, phloretin, and (+)-catechin] and the remaining flavonoids were mono- and diglycosides, whose sugar moiety consisted of glucose, galactose, arabinose, or other sugars. We reported about the specific features of E. longistipitata flavonoids in more detail in our previous article [11]. In addition, here we were able to identify a quercetin diglycoside: quercetin-6$O-\beta$-D-xylopyranosyl- $\beta$-D-glucopyranoside (Table 1 ).

\subsection{Fatty-Acid-Related Compounds}

In the analyzed extracts of E. longistipitata leaves, 14 fatty acid-related compounds were identified (Table 1). Mostly, these are long-chain fatty acids, octadecanoids with hydroxyl substituents, oxylipins, and hydroxypolyunsaturated fatty acids. The identified fatty acids play an important role in the metabolism of plant organisms and have various types of biological activity [17,18]. For example, 9-oxo-ODA, by acting on peroxisome proliferator-activated receptor, inhibits cellular triglyceride accumulation in hepatocytes and can be used against disorders of lipid metabolism [19]. 12-Oxo-phytodienoic acid is affiliated with jasmonates: oxylipins that serve as key signaling compounds in immunity, germination, and development of plants [20,21]. 12-Oxo-phytodienoic acid plays an important part in plant resistance to water-deficit conditions by regulating stomatal aperture [22]; its anti-inflammatory activity is documented [23]. Previously, the fatty acid profile was characterized only in the seeds of E. hyemalis, even though the fatty acid profiles differ among individual genera of the Ranunculaceae family and may have taxonomic significance [24].

\subsection{Coumarins}

Natural compounds that are based on 5,6-benzo- $\alpha$-pyrone are known as coumarins. Investigation into the chemistry of coumarins from the Ranunculaceae family began in the last century and continues to develop rapidly at present. The stimuli for these research advances are, on the one hand, the high variety of natural coumarins, and on the other hand, the practical value of many of these compounds as biologically-active substances. In E. longistipitata, four substances that were related to coumarins were identified here: 5,7-dihydroxy-4-methylcoumarin, scoparone, fraxetin, and luvangetin (Table 1, Figure 2). The first three compounds consist of a coumarin molecule with the following substituents: hydroxyl groups at positions C-5 and C-7 and a methyl group at C-4 in 5,7-dihydroxy-4methylcoumarin; there are methoxy groups at positions C-6 and C-7 in scoparone, whereas fraxetin also contains a methoxy group at the C-6 position and two hydroxyl groups at positions C-7 and C-8. All these simple coumarins are widespread in the plant world and have various biological activities $[25,26]$. Due to the high biological activity and low toxicity of coumarins, the attention of researchers in recent years was focused on the antitumor effects of these substances. Coumarins are used in the treatment of renal cell carcinoma, leukemia, and prostate cancer and have the ability to counteract the adverse effects of radiotherapy [27]. 
<smiles>Cc1cc(=O)oc2cc(O)cc(O)c12</smiles>

$5,7-$<smiles>COc1cc2ccc(=O)oc2cc1OC</smiles>

scoparone<smiles>COc1cc2ccc(=O)oc2c(O)c1O</smiles>

fraxetin

dihydroxy-4-methylcoumarin<smiles>COc1c2c(cc3ccc(=O)oc13)C=CC(C)(C)O2</smiles>

Coumarins

luvangetin

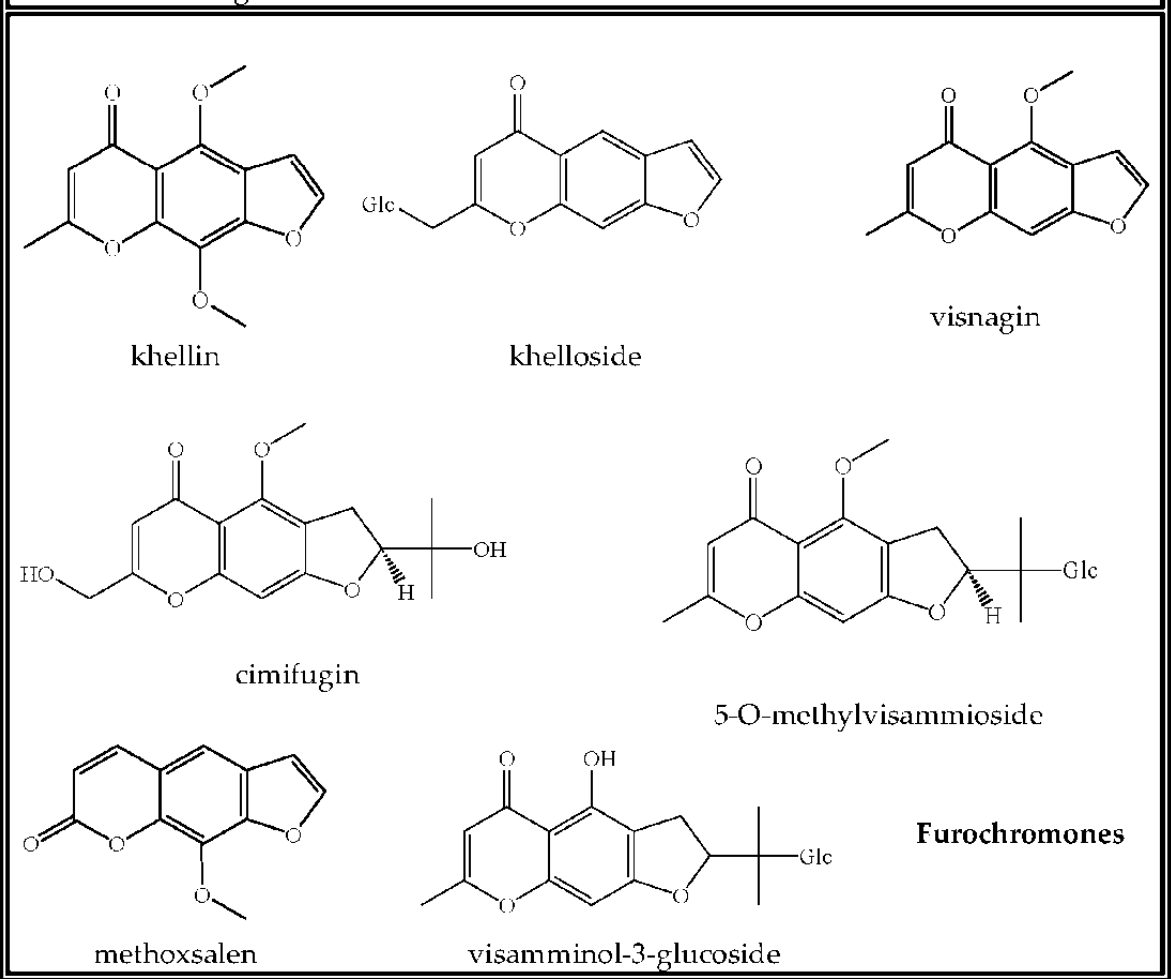

Figure 2. Structures of coumarins and furochromones from E. longistipitata.

Via the addition of a pyran ring, simple coumarins can be converted to pyranocoumarins, such as luvangetin which was found in E. longistipitata here. Luvangetin is a linear pyranocoumarin consisting of a six-membered ring that is linked to the benzene site of a benzopyran ring with a double bond at the $C-3^{\prime}\left(4^{\prime}\right)$ position and a methoxyl group at C-8. Luvangetin possesses impressive biological properties such as antiulcer [28] and antibacterial [29] effects and antifungal activity against Fusarium graminearum Schwabe, Rhizoctonia solani J.G. Kuhn, and Pyricularia oryzae Cavara [30]. The gastroprotective effect of luvangetin is not fully characterized because at a concentration of $1-10 \mu \mathrm{g} / \mathrm{mL}$, it does not induce additional production of prostaglandins as previously thought; luvangetin probably stimulates other protective actions of the mucous membrane [31].

\subsection{Chromones}

Chromones, a group of secondary metabolites that are based on 4H-1-benzopyran-4one, are considered common among a relatively limited number of plant species that are affiliated with families Ranunculaceae, Apiaceae Lindl., and Fabaceae Lindl., and some 
others [32]. Among the Ranunculaceae species, chromones have been found only in species of Eranthis [12-16,33] and of Actaea L. (sin. Cimicifuga Wermisch.) [34-38]. In terms of their structure, chromones are close to coumarins and flavonoids but are much less common in nature. Slightly more than 50 chromones are known, and their structural diversity has led to their tentative categorization into simple chromones and benzo-, pyrano-, and furo-chromones. Previously, in the Eranthis species that have been studied, compounds from the families of simple chromones and furochromones have been found (Table 2).

Table 2. Chromones that were previously found in Eranthis species.

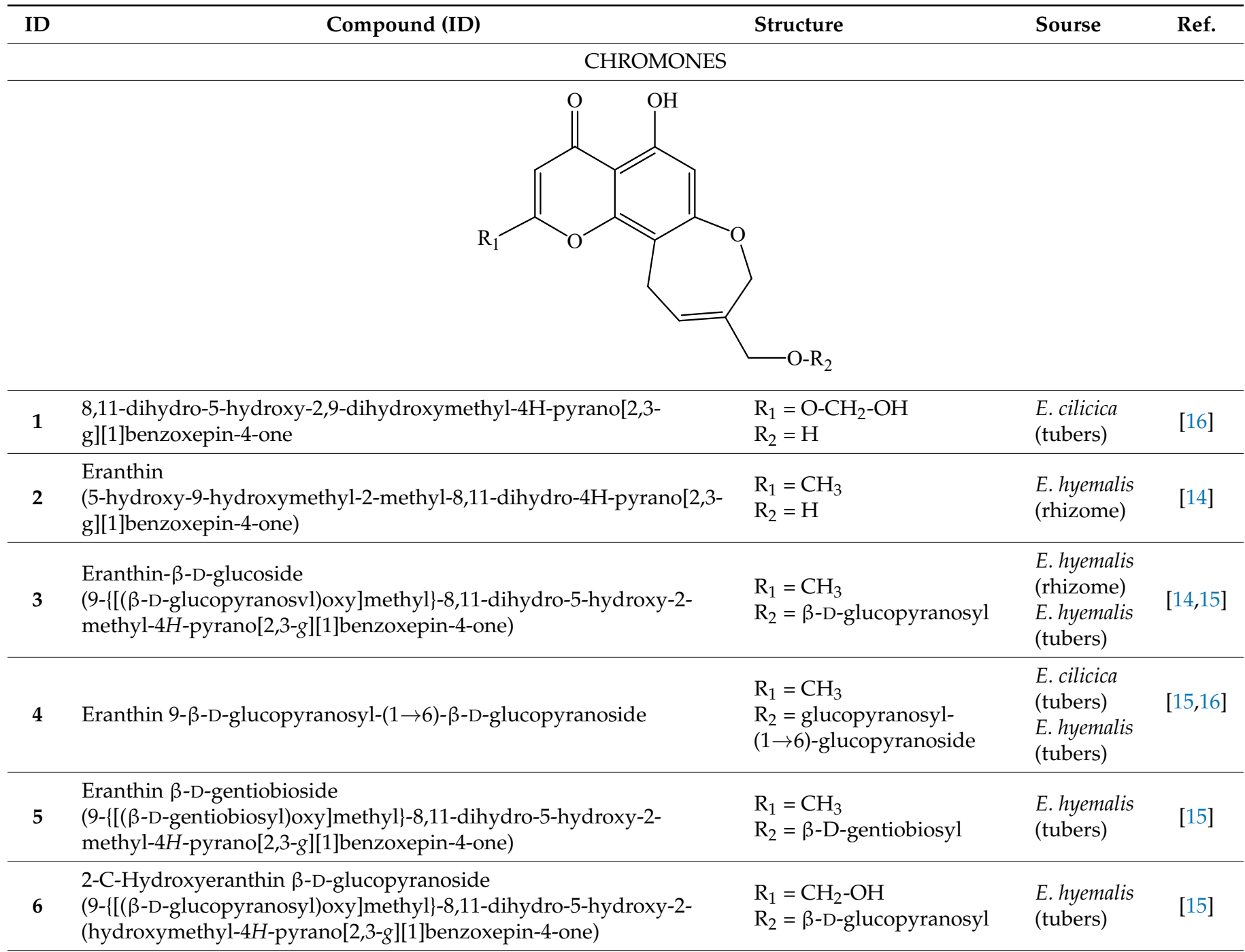<smiles>[R9]OC/C(C)=C/Cc1c(O[R20])cc(O)c2c(=O)cc([R])oc12</smiles> 
Table 2. Cont.

\begin{tabular}{|c|c|c|c|c|}
\hline ID & Compound (ID) & Structure & Sourse & Ref. \\
\hline 7 & $\begin{array}{l}\text { 5,7-dihydroxy-8-[(2E)-4-hydroxy-3-methylbut-2-enyl]-2-methyl-4H- } \\
\text { 1-benzopyran-4-one }\end{array}$ & $\begin{array}{l}\mathrm{R}_{1}=\mathrm{CH}_{3} \\
\mathrm{R}_{2}=\mathrm{R}_{3}=\mathrm{H}\end{array}$ & $\begin{array}{l}\text { E. cilicica } \\
\text { (tubers) }\end{array}$ & [16] \\
\hline 8 & $\begin{array}{l}\text { 5,7-dihydroxy-2-hydroxymethyl-8-[(2E)-4-hydroxy-3-methylbut-2- } \\
\text { enyl]-4H-1-benzopyran-4-one }\end{array}$ & $\begin{array}{l}\mathrm{R}_{1}=\mathrm{CH}_{2}-\mathrm{OH} \\
\mathrm{R}_{2}=\mathrm{R}_{3}=\mathrm{H}\end{array}$ & $\begin{array}{l}\text { E. cilicica } \\
\text { (tubers) }\end{array}$ & [16] \\
\hline 9 & $\begin{array}{l}\text { 7-[( } \beta \text {-D-glucopyranosyl)oxy]-5-hydroxy-8-[(2E)-4-hydroxy-3- } \\
\text { methylbut-2-enyl]-2-methyl-4H-1-benzopyran-4-one }\end{array}$ & $\begin{array}{l}\mathrm{R}_{1}=\mathrm{CH}_{3} \\
\mathrm{R}_{2}=\beta \text {-D-glucopyranosyl } \\
\mathrm{R}_{3}=\mathrm{H}\end{array}$ & $\begin{array}{l}\text { E. cilicica } \\
\text { (tubers) }\end{array}$ & [16] \\
\hline 10 & $\begin{array}{l}\text { 7-[( } \beta \text {-D-glucopyranosyl)oxy]-5-hydroxy-2-hydroxymethyl-8-[(2E)-4- } \\
\text { hydroxy-3-methylbut-2-enyl]-4H-1-benzopyran-4-one }\end{array}$ & $\begin{array}{l}\mathrm{R}_{1}=\mathrm{CH}_{2}-\mathrm{OH} \\
\mathrm{R}_{2}=\beta \text {-D-glucopyranosyl } \\
\mathrm{R}_{3}=\mathrm{H}\end{array}$ & $\begin{array}{l}\text { E. cilicica } \\
\text { (tubers) }\end{array}$ & [16] \\
\hline 11 & $\begin{array}{l}\text { 7,8-Secoeranthin } \beta \text {-D-glucoside } \\
\text { (8-\{(2E)-4-[( } \beta \text {-D-glucopyranosyl)oxy]-3-methylbut-2-enyl }\}-5,7- \\
\text { dihydroxy-2-methyl-4H-1-benzopyran-4-one })\end{array}$ & $\begin{array}{l}\mathrm{R}_{1}=\mathrm{CH}_{3} \\
\mathrm{R}_{2}=\mathrm{H} \\
\mathrm{R}_{3}=\beta-\text {-D-glucopyranosyl }\end{array}$ & $\begin{array}{l}\text { E. hyemalis } \\
\text { (tubers) }\end{array}$ & [15] \\
\hline 12 & $\begin{array}{l}\text { 2-C-Hydroxy-7,8-Secoeranthin } \beta \text {-D-glucoside } \\
\text { (8-\{(2E)-4-[( } \beta \text {-D-glucopyranosyl)oxy]-3-methylbut-2-enyl }\}-5,7- \\
\text { dihydroxy-2-(hydroxymethyl)-4H-1-benzopyran-4-one) }\end{array}$ & $\begin{array}{l}\mathrm{R}_{1}=\mathrm{CH}_{2}-\mathrm{OH} \\
\mathrm{R}_{2}=\mathrm{H} \\
\mathrm{R}_{3}=\beta-\text { - -glucopyranosyl }\end{array}$ & $\begin{array}{l}\text { E. hyemalis } \\
\text { (tubers) }\end{array}$ & [15] \\
\hline
\end{tabular}<smiles>[R]OCC1(O)C=Cc2c(cc(O)c3c(=O)cc(C)oc23)OC1</smiles>

9-[(O- $\beta$-D-glucopyranosyl-( $1 \rightarrow 6)-\beta$-D-glucopyranosyl)oxy]methyl-

13 8,11-dihydro-5,9-dihydroxy-2-methyl-4H-pyrano[2,3g][1]benzoxepin-4-one

$\mathrm{R}=$ glucopyranosyl-(1 $\rightarrow 6)-\quad$ E. cilicica glucopyranosyl (tubers)

8,11-dihydro-5,9-dihydroxy-9-hydroxymethyl-2-methyl-4Hpyrano[2,3-g][1]benzoxepin-4-one

$\begin{array}{ll}\mathrm{R}=\mathrm{H} & \begin{array}{l}\text { E. cilicica } \\ \text { (tubers) }\end{array}\end{array}$

\section{FUROCHROMONES}<smiles>[R7]OCc1cc(=O)c2c([R2])c3c(cc2o1)O[C@](C)(C(C)(C)O)C3</smiles>

\section{Cimifugin}

15 (2S)-7-(hydroxymethyl)-2-(2-hydroxypropan-2-yl)-4-methoxy-2,3dihydrofuro[3,2g]chromen-5-one)

$$
\begin{aligned}
& \mathrm{R}_{1}=\mathrm{H} \\
& \mathrm{R}_{2}=\mathrm{O}-\mathrm{CH}_{3}
\end{aligned}
$$

E. pinnatifida (leaves, stems) (tubers)

$\mathrm{R}_{1}=\beta$-D-glucopyranosyl $\mathrm{R}_{2}=\mathrm{O}-\mathrm{CH}_{3}$ methylethyl)-4-methoxy-5H-furo[3,2-g][1]benzopyran-5-one) 
Table 2. Cont.

\begin{tabular}{llll}
\hline ID & \multicolumn{1}{c}{ Compound (ID) } & Structure & \multicolumn{1}{c}{ Sourse } \\
\hline \multirow{2}{*}{$\mathbf{1 7}$} & $\begin{array}{l}\text { Norcimifugin } \\
\text { (2S)-4-hydroxy-7-(hydroxymethyl)-2-(2-hydroxypropan-2-yl)-2,3- } \\
\text { dihydrofuro[3,2-g]-chromen-5-one) }\end{array}$ & $\begin{array}{l}\mathrm{R}_{1}=\mathrm{H} \\
\mathrm{R}_{2}=\mathrm{OH}\end{array}$ & $\begin{array}{l}\text { E. pinnatifida } \\
\text { (leaves, } \\
\text { stems) }\end{array}$ \\
\hline
\end{tabular}

\begin{tabular}{|c|c|c|c|c|}
\hline 18 & $\begin{array}{l}\text { Visnagin } \\
\text { (4-methoxy-7-methyl-5H-furo[3,2-g]chromen-5-one) }\end{array}$ & $\begin{array}{l}\mathrm{R}_{1}=\mathrm{R}_{2}=\mathrm{H} \\
\mathrm{R}_{3}=\mathrm{O}-\mathrm{CH}_{3}\end{array}$ & E. hyemalis & [33] \\
\hline 19 & $\begin{array}{l}\text { Khellin } \\
\text { (4,9-dimethoxy-7-methyl-5H-furo[3,2-g]chromen-5-one) }\end{array}$ & $\begin{array}{l}\mathrm{R}_{1}=\mathrm{O}-\mathrm{CH}_{3} \\
\mathrm{R}_{2}=\mathrm{H} \\
\mathrm{R}_{3}=\mathrm{O}-\mathrm{CH}_{3}\end{array}$ & E. hyemalis & [33] \\
\hline 20 & $\begin{array}{l}\text { Khellol } \\
\text { (7-(hydroxymethyl)-4-methoxyfuro[3,2-g]chromen-5-one) }\end{array}$ & $\begin{array}{l}\mathrm{R}_{1}=\mathrm{H} \\
\mathrm{R}_{2}=\mathrm{CH}_{2}-\mathrm{OH} \\
\mathrm{R}_{3}=\mathrm{O}-\mathrm{CH}_{3}\end{array}$ & $\begin{array}{l}\text { E. pinnatifida } \\
\text { (leaves, } \\
\text { stems) }\end{array}$ & [13] \\
\hline 21 & $\begin{array}{l}\text { Khellol glucoside } \\
\text { (khellinin; 2-hydroxymethyl-5-methoxyfuranochrome glucoside) }\end{array}$ & $\begin{array}{l}\mathrm{R}_{1}=\mathrm{H} \\
\mathrm{R}_{2}= \\
\mathrm{CH}_{2}-\beta-\mathrm{D}-\text { glucopyranoside } \\
\mathrm{R}_{3}=\mathrm{O}-\mathrm{CH}_{3}\end{array}$ & $\begin{array}{l}\text { E. hyemalis } \\
\text { (leaves, } \\
\text { flowers) }\end{array}$ & [12] \\
\hline 22 & $\begin{array}{l}\text { Norkhellol } \\
\text { (4-hydroxy-7-(hydroxymethyl)-5H-furo[3,2-g][1]benzopyran-5-one) }\end{array}$ & $\begin{array}{l}\mathrm{R}_{1}=\mathrm{H} \\
\mathrm{R}_{2}=\mathrm{CH}_{2}-\mathrm{OH} \\
\mathrm{R}_{3}=\mathrm{OH}\end{array}$ & $\begin{array}{l}\text { E. pinnatifida } \\
\text { (leaves, } \\
\text { stems) }\end{array}$ & [13] \\
\hline 23 & $\begin{array}{l}\text { Norammiol } \\
\text { (4-hydroxy-7(hydroxymethyl)-9-methoxy-5H-furo[3,2-g][1]- } \\
\text { benzopyran-5-one) }\end{array}$ & $\begin{array}{l}\mathrm{R}_{1}=\mathrm{O}-\mathrm{CH}_{3} \\
\mathrm{R}_{2}=\mathrm{CH}_{2}-\mathrm{OH} \\
\mathrm{R}_{3}=\mathrm{OH}\end{array}$ & $\begin{array}{l}\text { E. pinnatifida } \\
\text { (leaves, } \\
\text { stems) }\end{array}$ & [13] \\
\hline 24 & $\begin{array}{l}\text { 7-[(O- } \beta \text {-D-glucopyranosyl-( } 1 \rightarrow 6)-\beta \text {-D-glucopyranosyl)oxy]methyl- } \\
\text { 4-hydroxy-5H-furo[3,2-g][1]benzopyran-5-one (24) }\end{array}$ & $\begin{array}{l}\mathrm{R}_{1}=\mathrm{H} \\
\mathrm{R}_{2}=\mathrm{CH}_{2} \text {-O-glucopyranosyl- } \\
(1 \rightarrow 6) \text {-glucopyranosyl } \\
\mathrm{R}_{3}=\mathrm{OH}\end{array}$ & $\begin{array}{l}\text { E. cilicica } \\
\text { (tubers) }\end{array}$ & [16] \\
\hline
\end{tabular}

In the series of substances 1-6, substituents vary at positions C-2 and C-12. At C-2, it is either a methyl group or a hydroxymethyl group whereas at the $\mathrm{C}-12$ position: mono- and diglycosides. In compounds $\mathbf{7 - 1 2}$, the oxepin ring is open and the $4^{\prime}$-hydroxy-3'-methylbut$2^{\prime}$-enyl group is fixed at the C-8 position. D-Glucose can be present at the C-7 position (as in compounds 9 and 10) or at the C-4' position (as in compounds 11 and 12). Compounds 13 and $\mathbf{1 4}$ are close in structure to substances 1-6, and the differences are as follows: the double bond in the oxepine ring is shifted from C-9(10) to C-10(11), respectively, and C-9 carries not only the oxymethylene group with various substituents but also a hydroxyl group.

Most often, the presence of simple chromones has been registered in the underground part of Eranthis species, whereas furochromones have been identified in both the underground and aboveground parts (Table 2).

The furochromones that have been registered in Eranthis species are represented by cimifugin (15) and two of its derivatives: cimicifugin $\beta$-D-glucopyranoside (16) and norcimifugin (17). Khellin (19) is a furanochromone derivative in which there are methoxy groups at positions C-4 and C-9 and a methyl group at the C-7 position (Table 2). Visnagin (18) is based on the furanochromone framework too but has substituents at positions C-4 and C-7 (methoxy and methyl groups, respectively), but there are no substituents at the C-9 position. Khellol (20) is an aglycone of khellol glucoside (21), whose sugar moiety is 
attached at the C-7 position. The next two compounds that were previously found in the leaves and stems of E. pinnatifida differ from each other by the presence of a hydroxymethyl group at the C-9 position [in norammiol (23)] or its absence [in norkhellol (22)] [13]. The furochromone that was identified in tubers of E. cilicica (24) is a diglucoside [16].

In our extracts of E. longistipitata, the class of chromones is represented by seven compounds belonging to the family of furochromones (Table 1, Figure 2). The latter are formed via condensation of simple chromones with a furan ring at positions C-6 and C-7. Cimifugin (15) has been detected previously in the leaves and stems of E. pinnatifida and in the tubers of E. cilicica; visnagin (18), khellin (19), and khellol glucoside (21) have been found in E. hyemalis, whereas khellol (20) in the leaves and stems of E. pinnatifida (Table 2). In our study, methoxsalen, 5-O-methylvisammioside, and visamminol-3'-O-glucoside were found in Eranthis for the first time. Methoxsalen is a naturally occurring analog of psoralen and is found in various species of Rutaceae Juss, Fabaceae, and Apiaceae [39-41]. Earlier, 5-O-methylvisammioside was isolated from the underground part (radix) of Saposhnikovia divaricata (Turcz. ex Ledeb.) Schischk. (Apiaceae) [42].

The pharmacological activity of furochromones and their limited occurrence are of interest. Chromone derivatives possess anti-inflammatory, antiviral, and antitumor activities and are employed as antioxidants. In addition, due to their photochemical properties, they can serve as fluorescent labels in biochemical experiments and clinical practice. Chromones, with electron-withdrawing substituents at the C-3 position, form the basis for the synthesis of various heterocyclic compounds [43-45]. The first chromone to be used in clinical practice was khellin, which is isolated from the seeds of Ammi visnaga (L.) Lam. [45]. Khellin and visnagin can serve as bioherbicides [46] and an anti-inflammatory activity of 5-O-methylvisammioside has been reported [47], whereas cimifugin effectively inhibits allergic inflammatory reactions [48]. Some chromones that were isolated from Eranthis exert antioxidant action on the superoxide anion [16].

According to comprehensive molecular and morphological analyses, the genus Eranthis is affiliated with Ranunculaceae tribe Cimicifugeae, which includes genera Actaea (incl. Cimicifuga and Souliea Franch.), Anemonopsis Siebold \& Zucc., Beesia Balf.f. \& W.W.Sm., and Eranthis [3]. On the basis of morphological similarity with the genus Helleborus L., some investigators have assigned Eranthis to the tribe Helleboreae DC., subtribe Helleborinae Jensen [49-51]. On the other hand, ongoing research in the field of Helleborus phytochemistry indicates that a distinctive feature of this genus is the accumulation of substances from the class of cardioactive glycosides: cardenolides and bufadienolides [52], which have not been found in Eranthis species. In phytochemical characteristics, Eranthis is closer to the genus Actaea because chromones are synthesized in these genera via normal physiological processes [53]. Our detection of furochromones in E. longistipitata is another proof of the close relationship between Eranthis and the genus Actaea.

\section{Materials and Methods}

\subsection{Plant Material and Preparation of the Extract}

The leaves of E. longistipitata were collected during the flowering-fruiting period in 2019 (Table 3). The plant material was dried by means of silica gel. The leaves were ground up to obtain a homogeneous powder. The set of compounds was studied in $70 \%$ aqueousethanol extracts of the leaves; these extracts were prepared at $72 \mathrm{C}$ in a WB-4MS water bath (Biosan, Riga, Latvia). A certain portion $(0.200 \mathrm{~g})$ of the crushed air-dried material was extracted twice: first, with $30 \mathrm{~mL}$ for $30 \mathrm{~min}$, and then, with $20 \mathrm{~mL}$ for $20 \mathrm{~min}$. "Yellow ribbon" filter paper (LLC Melior XXI, Reutov, Russia) was used to filter extracts. After filtration, the residue in the flask and on the filter was washed with $5 \mathrm{~mL}$ of $70 \%$ ethyl alcohol. The mixed extract was then concentrated in porcelain cups down to $5 \mathrm{~mL}$. Before the analysis, the solutions were filtered and stored at $4{ }^{\circ} \mathrm{C}$. 
Table 3. Sites of collection of the analyzed samples.

\begin{tabular}{cccc}
\hline Sample No. & Locality; Coordinates & Habitat & Date \\
\hline 1 & $\begin{array}{r}\text { Kyrgyzstan, Chuya region, Issyk-atinskii district, } \\
\text { Karandolot tract; } 42^{\circ} 44^{\prime} 22^{\prime \prime} \mathrm{N}, 74^{\circ} 55^{\prime} 50^{\prime \prime} \mathrm{E}\end{array}$ & foot of the mount & 22 March 2019 \\
\hline 2 & $\begin{array}{c}\text { Kyrgyzstan, Talas region, Kara-Burrinskii district, west of } \\
\text { Kirovskoe reservoir; } 42^{\circ} 37^{\prime} 57^{\prime \prime} \mathrm{N}, 71^{\circ} 34^{\prime} 47^{\prime \prime} \mathrm{E}\end{array}$ & steppe & 26 March 2019 \\
\hline
\end{tabular}

\subsection{MS Settings and the Spectral Library}

An aqueous-ethanol extract $(1 \mathrm{~mL})$ was diluted with double-distilled water to $5 \mathrm{~mL}$ and passed through a Diapak C16 concentrating cartridge (ZAO BioKhimMak, Moscow, Russia). The substances were washed off the cartridge with a small amount $(3 \mathrm{~mL})$ of $70 \%$ ethanol and then with $2 \mathrm{~mL}$ of $96 \%$ ethanol. The combined eluate was passed through a membrane filter with a pore diameter of $0.45 \mu \mathrm{m}$ (Restek, Shanghai, China).

LC-HRMS was carried out at the Core Facility of Mass-Spectrometric Analysis at the Institute of Chemical Biology and Fundamental Medicine SB RAS (Novosibirsk, Russia). An Ultimate 3000 liquid chromatograph (Thermo Fisher Scientific, San Jose, CA, USA) that was coupled with a Q Exactive HF mass spectrometer (Thermo Fisher Scientific) was utilized to determine metabolomic profiles of E. longistipitata leaves. The chromatographic separation was attained at a $0.4 \mathrm{~mL} / \mathrm{min}$ flow rate on a Zorbax Eclipse XDB-C18 reversed-phase column $(150 \times 3.0 \mathrm{~mm}, 5 \mu \mathrm{m}$, Agilent Technologies, Santa Clara, CA, USA) thermostatted at $40{ }^{\circ} \mathrm{C}$. The mobile phase was composed of $0.1 \%$ aqueous formic acid (eluent $\mathrm{A}$ ) and acetonitrile (eluent B). The elution gradient was implemented as follows: from $5 \%$ to $70 \% \mathrm{~B}$ for $40 \mathrm{~min}$, followed by an increase to $90 \% \mathrm{~B}$ for $8 \mathrm{~min}$, a decrease to $5 \% \mathrm{~B}$ for $5 \mathrm{~min}$, and re-equilibration under the initial conditions for $7 \mathrm{~min}$.

The settings of the ESI source were as follows: electrospray voltage: $3.2 \mathrm{kV}$ in the negative mode and $4.2 \mathrm{kV}$ in the positive mode; capillary temperature: $320^{\circ} \mathrm{C}$; and the $\mathrm{S}$ lens RF level: 50 . The data were obtained by full-scan data-dependent acquisition (FSdd-MS2) in the positive and negative modes at a resolving power of 45,000 full-width at half maximum (FWHM) at $m / z 200$. The following settings of the mass spectrometer were employed: the scan range, $m / z$ 80-1200; automatic gain control (AGC), 3e6; injection time, $100 \mathrm{~ms}$; and the isolation window, $m / z 2.0$. The normalized collision energy for the fragmentation of molecular ions was set to $40 \mathrm{eV}$. A targeted MS/MS (dd-MS2) analysis was performed in both the positive and negative modes at 15,000 FWHM (at $m / z 200$ ). AGC for dd-MS2 was set to $1 \times 10^{5}$, with an injection time of $50 \mathrm{~ms}$ and a loop count of 5 . In the section of dd settings, the AGC target was programmed at $8 \times 10^{3}$, and the maximum injection time was set to $100 \mathrm{~ms}$. The data were analyzed using Xcalibur 4.0 and Compound Discoverer 3.1 software (Thermo Fisher Scientific). All the samples, including the blank samples, were assayed in triplicate.

All the samples were processed in Compound Discoverer 3.1 via a common workflow called "Environmental Unknown ID w Online and Local Database Searches" (Figure S1 in Supplementary Material). A mass tolerance of $5 \mathrm{ppm}$ was applied to all nodes. Several databases, i.e., KEGG (https:/ / www.genome.jp/ kegg/; last accessed on 10 March 2021), MassBank (https: / / massbank.eu/MassBank/; last accessed on 10 March 2021), PlantCyc (https:/ / plantcyc.org/; last accessed on 10 March 2021), and Planta Piloto de Quimica Fina Universidad de Alcala (http:/ / www.cqab.eu/index.php/en/; last accessed on 10 March 2021), were chosen in ChemSpider.

The chemical constituents were identified on the basis of both accurate mass and fragment mass "fingerprint" spectra via searches against the spectra of compounds that were available in the mzCloud database (https:/ / www.mzcloud.org; last accessed on 10 March 2021). If compounds were absent in mzCloud, they were tentatively identified using a ChemSpider search. According to the workflow, the masses that were extracted from the chromatograms were aligned and filtered to remove (i) the background compounds that 
were present in the blank sample, (ii) substances that failed to become fragmented, (iii) compounds' masses that were absent in the databases, and (iv) signals with low intensity.

All the samples, including the blank samples, which consisted of the pure solvent, were analyzed as two biological replicates with three technical replicates per treatment group.

\subsection{Chemicals}

All chemicals were of MS or analytical grade. The chemical reference standards of quercetin and kaempferol were purchased from Sigma-Aldrich (Taufkirchen, Germany). Rutin and chemical reference standards of hyperoside were purchased from Fluka Chemie AG (Buchs, Switzerland).

\section{Conclusions}

Data on the overall metabolite profile of E. longistipitata leaves were obtained by LCHRMS for the first time. This method requires only a small amount of plant material and, therefore, is certainly suitable for the research on endemic plants of the genus Eranthis. A comparison of samples of E. longistipitata among different natural populations revealed no differences in the metabolome among the studied samples. Next, we more closely examined flavonoids in the metabolite profile (19 compounds). Additionally, coumarins (four compounds), amino acids (six), fatty (14) and organic acids (three), sugars (three), furochromones (seven), and other compounds were identified in the leaves. Flavonoids and fatty acids manifested the highest diversity; however, coumarins and furochromones that were found in E. longistipitata are more intriguing and are relatively rare in the plant kingdom. The proposed fine-tuned technique for the identification of substances in $E$. longistipitata leaves will help investigators to conduct further phytochemical and chemotaxonomic research on plant species from the genus Eranthis.

Supplementary Materials: The following are available online at https:/ / www.mdpi.com/article/ $10.3390 / \mathrm{ijms} 23010406 / \mathrm{s} 1$.

Author Contributions: Supervision: A.S.E. and V.A.K.; data curation: A.A.C. and V.A.K.; funding acquisition: A.S.E.; writing-review and editing: V.A.K., N.V.P., A.A.C. and W.W.; investigation, methodology: A.A.C. and V.A.K.; validation, writing-original draft preparation: A.A.C., V.A.K., N.V.P., M.S.K., S.Y.M., W.W. and A.S.E.; resources: A.S.E. All authors have read and agreed to the published version of the manuscript.

Funding: The coauthors who are not coinvestigators in Russian Science Foundation project No. 19-74-10082 were remunerated for labor (30\% of effort in the study) within state assignments for CSBG SB RAS (projects No. AAAA-A21-121011290024-5 and AAAA-A21-121011290025-2), for IPP RAS (No. 121041200194-7), for ICBFM SB RAS (0245-2021-0006), for BIN RAS (project No. AAA-A19119031290052-1), and for NSFC (No. 32011530072). The chemical analytical procedures and analysis and interpretation of the data (70\% of effort in the study) were funded by Russian Science Foundation project No. 19-74-10082 (for its participants who are coauthors of this study).

Institutional Review Board Statement: Not applicable.

Informed Consent Statement: Not applicable.

Data Availability Statement: Not applicable.

Acknowledgments: We thank Eugeny Boltenkov for the materials from Kyrgyzstan.

Conflicts of Interest: The authors declare no conflict of interest.

\section{References}

1. Doppler, M.; Kluger, B.; Bueschl, C.; Schneider, C.; Krska, R.; Delcambre, S.; Hiller, K.; Lemmens, M.; Schuhmacher, R. Stable isotope-assisted evaluation of different extraction solvents for untargeted metabolomics of plants. Int. J. Mol. Sci. 2016, 17, 1017. [CrossRef]

2. Abuzaid, H.; Amin, E.; Moawad, A.; Abdelmohsen, U.R.; Hetta, M.; Mohammed, R. Liquid Chromatography High Resolution Mass Spectrometry Analysis, Phytochemical and Biological Study of Two Aizoaceae Plants: A New Kaempferol Derivative from Trianthema portulacastrum L. Pharmacogn. Res. 2020, 12, 212. [CrossRef] 
3. Wang, W.; Lu, A.M.; Ren, Y.; Endress, M.E.; Chen, Z.D. Phylogeny and classification of Ranunculales: Evidence from four molecular loci and morphological data. Perspect. Plant Ecol. Evol. Syst. 2009, 11, 81-110. [CrossRef]

4. Oh, A.; Oh, B.U. The speciation history of northern- and southern-sourced Eranthis (Ranunculaceae) species on the Korean peninsula and surrounding areas. Ecol. Evol. 2019, 9, 2907-2919. [CrossRef]

5. $\quad$ Park, S.Y.; Jeon, M.J.; Ma, S.H.; Wahlsteen, E.; Amundsen, K.; Kim, J.H.; Suh, J.K.; Chang, J.S.; Joung, Y.H. Phylogeny and genetic variation in the genus Eranthis using nrITS and cpIS singlenucleotide polymorphisms. Hortic. Environ. Biotechnol. 2019, 60, 239-252. [CrossRef]

6. $\quad$ Erst, A.S.; Sukhorukov, A.P.; Mitrenina, E.Y.; Skaptsov, M.V.; Kostikova, V.A.; Chernisheva, O.A.; Troshkina, V.; Kushunina, M.; Krivenko, D.A.; Ikeda, H.; et al. An integrative taxonomic approach reveals a new species of Eranthis (Ranunculaceae) in North Asia. PhytoKeys 2020, 140, 75-100. [CrossRef]

7. Mitrenina, E.Y.; Erst, A.S.; Peruzzi, L.; Skaptsov, M.V.; Ikeda, H.; Nikulin, V.Y.; Wang, W. Karyotype and genome size variation in white-flowered Eranthis sect. Shibateranthis (Ranunculaceae). PhytoKeys 2021, in press.

8. Watanabe, K.; Mimaki, Y.; Sakuma, C.; Sashida, Y. Eranthisaponins A and B, two new bisdesmosidic triterpene saponins from the tubers of Eranthis cilicica. J. Nat. Prod. 2003, 66, 879-882. [CrossRef]

9. Watanabe, K.; Mimaki, Y.; Fukaya, H.; Matsuo, Y. Cycloartane and oleanane glycosides from the tubers of Eranthis cilicica. Molecules 2019, 24, 69. [CrossRef] [PubMed]

10. Kostikova, V.A.; Erst, A.S.; Kuznetsov, A.A.; Gureyeva, I.I. Levels of phenolic compounds in leaves of Eranthis sibirica, E. stellata and E. tanhoensis (Ranunculaceae). Ukr. J. Ecol. 2020, 10, 232-237. [CrossRef]

11. Kostikova, V.A.; Chernonosov, A.A.; Kuznetsov, A.A.; Petrova, N.V.; Krivenko, D.A.; Chernysheva, O.A.; Wang, W.; Erst, A.S Identification of Flavonoids in the Leaves of Eranthis longistipitata (Ranunculaceae) by Liquid Chromatography with HighResolution Mass Spectrometry (LC-HRMS). Plants 2021, 10, 2146. [CrossRef]

12. Egger, K. Khellolglucosid in Eranthis hiemalis. Z. Naturforsch. 1961, 16, 697-702. [CrossRef]

13. Wada, H.; Gaino, M.; Saito, S. Furochromones of Erantis pinnatifida. Phytochemistry 1974, 13, 297-299. [CrossRef]

14. Junior, P. Eranthin and eranthin- $\beta$-D-glucoside: Two new chromones from Eranthis hiemalis. Phytochemistry 1979, 18, 2053-2054. [CrossRef]

15. Kopp, B.; Kubelka, E.; Reich, C.; Robien, W.; Kubelka, W. 4-H-Chromenone glycosides from Eranthis hyemalis (L.) Salisbury. Helv. Chim. Acta. 1991, 74, 611-616. [CrossRef]

16. Kuroda, M.; Uchida, S.; Watanabe, K.; Mimaki, Y. Chromones from the tubers of Eranthis cilicica and their antioxidant activity Phytochemistry 2009, 70, 288-293. [CrossRef] [PubMed]

17. Maltsev, Y.; Maltseva, K. Fatty acids of microalgae: Diversity and applications. Rev. Environ. Sc. Biotechnol. 2021, 20, 515-547. [CrossRef]

18. Maltsev, Y.; Maltseva, K.; Kulikovskiy, M.; Maltseva, S. Influence of light conditions on microalgae growth and content of lipids, carotenoids and fatty acid composition. Biology 2021, 10, 1060. [CrossRef] [PubMed]

19. Kim, Y.; Hirai, S.; Takahashi, H.; Goto, T.; Ohyane, C.; Tsugane, T.; Konishi, C.; Fujii, T.; Inai, S.; Iijima, Y.; et al. 9-oxo-10(E),12(E)Octadecanoic acid derived from tomato is a potent PPAR $\alpha$ agonist to decrease triglyceride accumulation in mouse primary hepatocytes. Mol. Nutr. Food Res. 2011, 55, 585-593. [CrossRef]

20. Taki, N.; Sasaki-Sekimoto, Y.; Obayashi, T.; Kikuta, A.; Kobayashi, K.; Ainai, T.; Yagi, K.; Sakurai, N.; Suzuki, H.; Masuda, T.; et al. 12-Oxo-phytodienoic acid triggers expression of a distinct set of genes and plays a role in wond-induced gene expression in Arabidopsis. Plant. Physiol. 2005, 139, 1268-1283. [CrossRef]

21. Wasternack, C.; Hause, B. Jasmonates: Biosynthesis, perception, signal transduction and action in plant stress response, growth and development. An update to the 2007 review in Annals of Botany. Ann. Bot. 2013, 111, 1021-1058. [CrossRef]

22. Savchenko, T.V.; Zastrijnaja, O.M.; Klimov, V.V. Oxylipins and plant abiotic stress resistance. Biochemistry 2014, 79, 362-375. [CrossRef] [PubMed]

23. Taki-Nakano, N.; Kotera, J.; Ohta, H. 12-Oxo-phytodienoic acid, a plant-derived oxylipin, attenuates lipopolysaccharide-induced inflammation in microglia. Biochem. Biophys. Res. Commun. 2016, 473, 1288-1294. [CrossRef] [PubMed]

24. Aitzetmüller, K. An unusual fatty acid pattern in Eranthis seed oil. Lipids 1996, 31, 201-205. [CrossRef] [PubMed]

25. Hui, Y.; Wang, X.; Yu, Z.; Fan, X.; Cui, B.; Zhao, T.; Mao, L.; Feng, H.; Lin, L.; Yu, Q.; et al. Scoparone as a therapeutic drug in liver diseases: Pharmacology, pharmacokinetics and molecular mechanisms of action. Pharm. Res. 2020, 160, 105170. [CrossRef]

26. Xu, H.; Zhang, Q.; Wang, Q.; Li, Y.; Zhang, B. Fraxetin inhibits the proliferation of RL95-2 cells through regulation of metabolism. Int. J. Clin. Exp. Pathol. 2020, 13, 1500-1505. [PubMed]

27. Küpeli Akkol, E.; Genç, Y.; Karpuz, B.; Sobarzo-Sánchez, E.; Capasso, R. Coumarins and Coumarin-Related Compounds in Pharmacotherapy of Cancer. Cancers 2020, 12, 1959. [CrossRef]

28. Srivastava, S.D.; Halwe, K.; Srivastava, S.K. New coumarins from Limonia crenulata. Fitoterapia 1997, 68, 410-412.

29. Chakraborty, D.P.; Sen, M.; Bose, P.K. On the antibiotic activity of some natural coumarins. Trans. Bose Rees. Inst. $1961,24,31$.

30. Xiong, Y.; Huang, G.; Yao, Z.; Zhao, C.; Zhu, X.; Wu, Q.; Zhou, X.; Li, J. Screening effective antifungal substances from the bark and leaves of Zanthoxylum avicennae by the bioactivity-guided isolation method. Molecules 2019, 24, 4207. [CrossRef]

31. Goel, R.K.; Maiti, R.N.; Manickam, M.; Ray, A.B. Antiulcer activity of naturally occurring pyrano-coumarin and isocoumarins and their effecton prostanoid synthesis using human colonic mucosa. Indian J. Exp. Biol. 1997, 35, 1080-1083. 
32. Harborne, J.B.; Baxter, H.; Moss, G.P. Phytochemical dictionary A Handbook of Bioactive Compounds from Plants; Taylor and Francis: London, UK, 1999; pp. 381-389.

33. Harborne, J.B. Biochemistry of Phenolic Compounds; Academic Press: New York, NY, USA, 1964; 88p.

34. Cao, P.; Pu, X.F.; Peng, S.L.; Zhang, X.R.; Ding, L.S. Chemical constituents from Cimicifuga foetida. J. Asian Nat. Prod. Res. 2005, 7, 145-149. [CrossRef]

35. Lu, L.; Chen, J.C.; Li, Y.; Qing, C.; Wang, Y.Y.; Nian, Y.; Qiu, M.H. Studies on the constituents of Cimicifuga foetida collected in Guizhou province and their cytotoxic activities. Chem. Pharm. Bull. 2012, 60, 571-577. [CrossRef] [PubMed]

36. Huyen, C.T.T.; Luyen, B.T.T.; Khan, G.J.; Oanh, H.V.; Hung, T.M.H.; Li, H.J.; Li, P. Chemical comstituents from Cimicifuga dahurica and their anti-proliferative effects on MCF-7 breast cancer cells. Molecules 2018, 23, 1083. [CrossRef]

37. Shi, Q.Q.; Lu, J.; Peng, X.R.; Li, D.S.; Zhou, L.; Qiu, M.H. Cimitriteromone A-G, macromolecular triterpenoid-chromone hybrids from rhizomes of Cimicifuga foetida. J. Org. Chem. 2018, 83, 10359-10369. [CrossRef]

38. Shi, Q.Q.; Gao, Y.; Lu, J.; Zhou, L.; Qiu, M.H. Two new triterpenoid-chromone hybrids from the rhizomes of Actaea cimicifuga L. (syn. Cimicifuga foetida L.) and their cytotoxic activities. Nat. Prod. Res. 2022, 36, 193-199. [CrossRef] [PubMed]

39. Al-Khateb, E.H.; Al-Shamma, A.A.; Nehar, B.A. A study of the furocoumarin derivative of Ruta chalepensis L. (Rutaceae). Iraqi J. Pharm. Sci. 2006, 15, 10-15. [CrossRef]

40. Kaboodi, P.S.; Moghadamnia, A.A.; Bakhshi, D.; Sefidgar, A.A. A study of phytochemical properties of various extracts of Ammi majus fruit using GC-MS technique. Ecol. Environ. Conserv. 2017, 23, 150-155.

41. Alam, F.; Khan, G.N.; Asad, M.H.H.B. Psoralea corylifolia L.: Ethnobotanical, biological, and chemical aspects: A review. Phytother. Res. 2018, 32, 597-615. [CrossRef]

42. Liu, R.; Wu, S.; Sun, A. Separation and purification of four chromones from radix saposhnikoviae by high-speed counter-current chromatography. Phytochem. Anal. 2008, 19, 206-211. [CrossRef] [PubMed]

43. Gaspar, A.; Matos, M.J.; Garrido, J.; Uriarte, E.; Borges, F. Chromones: A valid scaffold in medicinal chemistry. Chem. Rev. 2014, 114, 4960-4992. [CrossRef] [PubMed]

44. Keri, R.S.; Budagumpi, S.; Pai, R.K.; Balakrishna, G. Chromones as a privileged scaffold in drug discovery: A review. Eur. J. Med. Chem. 2014, 78, 340-374. [CrossRef] [PubMed]

45. Vanguru, M.; Merugu, R.; Garimella, S.; Laxminarayana, E. A review on the synthetic methodologies of chromones. Asian J. Pharm. Clin. Res. 2018, 11, 9-16. [CrossRef]

46. Travaini, M.L.; Sosa, G.M.; Ceccarelli, E.A.; Walter, H.; Cantrell, C.L.; Carrillo, N.J.; Dayan, F.E.; Meepagala, K.M.; Duke, S.O. Khellin and visnagin, furanochromones from Ammi visnaga (L.) Lam., as potential bioherbicides. Agric. Food Chem. 2016, 64, 9475-9487. [CrossRef]

47. Kang, J.S.; Chin, Y.W.; Lee, K.; Kim, Y.W.; Choi, B.Y.; Keum, Y.S. Identification of 4-O- $\beta$-D-glucosyl-5-O-methylvisamminol as a novel epigenetic suppressor of histone $\mathrm{H} 3$ phosphorylation at Ser10 and its interaction with 14-3-3e. Bioorg. Med. Chem. Lett. 2014, 24, 4763-4767. [CrossRef]

48. Wang, X.; Jiang, X.; Yu, X.; Liu, H.; Tao, Y.; Jiang, G.; Hong, M. Cimifugin suppresses allergic inflammation by reducing epithelial derived initiative key factors via regulating tight junctions. J. Cell. Mol. Med. 2017, 21, 2926-2936. [CrossRef] [PubMed]

49. Langlet, O.F.J. Über Chromosomen verhältnisse und systematic der Ranunculaceae. Svensk. Bot. Tidskr. 1932, 26, 318-400.

50. Tamura, M. Ranunculaceae. In The families and genera of vascular plants, Vol. II Flowering plants, Dicotyledons, Magnoliid, Hamamelid and Caryophyllid Families; Kubitzki, K., Rohwer, J.G., Bittrichet, V., Eds.; Springer: Berlin, Germany, 1993; Volume 2, pp. 563-583.

51. Hoot, S.B. Phylogeny of the Ranunculaceae based on epidermal microcharacters and micromorphology. Syst. Bot. 1991, 16, 741-755. [CrossRef]

52. Maior, M.C.; Dobrotă, C. Natural compounds with important medical potential found in Helleborus sp. Cent. Europ. J. Biol. 2013, 8, 272-285. [CrossRef]

53. Gao, J.C.; Peng, Y.; Yang, M.S.; Xiao, P.G. A preliminary pharmacophylogenetic study of tribe Cimicifugeae (Ranunculaceae). J. Syst. Evol. 2008, 46, 516-536. [CrossRef] 